\title{
PERKEMBANGAN TEKNOLOGI KOMUNIKASI DALAM ERA JURNALISTIK MODERN
}

\author{
Ido Prijana Hadi \\ Jurusan Ilmu Komunikasi, Fakultas Ilmu Komunikasi \\ Universitas Kristen Petra \\ Jalan Siwalankerto 121-131 Surabaya 60236 \\ Email: ido@peter.petra.ac.id
}

\begin{abstract}
Internet technology has made communication much easier and less expensive. It has attracted many people and has penetrated into people's daily lives. The mass media also have accepted the internet. Almost all forms of traditional media, such as radio, television, and newspaper have extended their work into this new field. The internet and the world wide web have both significantly influenced modern journalism. Many television, radio broadcasting stations, and newspapers in Indonesia operate their sites using internet technology. Internet brings a technical communication revolution, a fundamental change takes place in the structure of connections, artificial memories and the reproduction of their content. In online media allows readers to enjoy browsing their product and service of contents, such as news feed, podcasts, deskstop alert, news on mobile phones, PDA and others mobile devices. Online media offer not only text but also digital images, audio file, and moving images (video). The interactive features of the internet seemingly imply that online media have more advantages than traditional media forms. So, the internet have dramatically evolved become new media with characteristic multimedia, hypertext, interactivity, archives, and virtuality. The most important structural new media characteristic is the integration of telecommunications, data communications and mass communication in a single medium. It is the process of convergence.
\end{abstract}

Keywords: modern journalism, convergence, multimedia.

\section{PENDAHULUAN}

Teknologi dalam perkembangan arus produksi, konsumsi dan distribusi informasi memegang peranan penting. Urgensi peranan teknologi dalam proses massifikasi informasi terjadi ketika hasil teknologi membantu mengubah pola komunikasi yang dibatasi oleh ruang dan waktu menjadi pola komunikasi informasi tanpa batas. Sehingga hadirnya media baru (new media) ${ }^{1}$ memberi alternatif masyarakat dalam mencari dan memanfaatkan sumber-sumber informasi untuk memenuhi kebutuhannya. Media massa konvensional (tv, radio dan cetak) dituntut

\footnotetext{
1 Definisi new media secara eksklusif merujuk pada teknologi komputer yang menekankan bentuk dan konteks budaya yang mana teknologi digunakan, seperti dalam seni, film, perdagangan, sains dan diatas itu semua internet. Sementara digital media merupakan kecenderungan kepada kebebasan teknologi itu sendiri sebagai karakteristik sebuah medium, atau merefleksikan teknologi digital (Dewdney and Ride. 2006: 8 \& 20).
} 
untuk melakukan intergrasi dengan media baru agar mampu memenuhi harapan baru bagi pelanggan setianya, baik pembaca online maupun cetak.

Perkembangan media baru sebenarnya merujuk kepada sebuah perubahan dalam proses produksi media, distribusi dan penggunaan. Media baru tidak terlepas dari key term seperti digitality, interactivity, hypertextuality, dispersal dan virtuality (Lister, 2003 : 13). Dalam konsep digitality semua proses media digital diubah (disimpan) ke dalam bilangan, sehingga keluarannya (out put) dalam bentuk sumber online, digital disk, atau memory drives yang akan diubah dan diterima dalam layar monitor atau dalam bentuk 'hard copy'. Konsep Interactivity merujuk kepada adanya kesempatan dimana teks dalam media baru mampu memberikan users untuk 'write back into the text'. Sedangkan konsep dispersal media baru lebih kepada proses produksi dan distribusi media menjadi decentralised dan mengandalkan keaktifan individu (highly individuated). Batasan new media sering disamakan dengan digital media, yang semestinya new media lebih pada konteks dan konsep budaya kontemporer dari parktik media daripada seperangkat teknologi itu sendiri (medium).

Misalnya pada 13 Agustus 2008 Indonesia telah menapak ke pintu teknologi penyiaran televisi digital. Peristiwa itu berupa soft launching siaran TV digital ${ }^{2}$ oleh TVRI. Teknologi TV digital dipilih karena punya banyak kelebihan dibandingkan dengan analog. Teknologi ini punya ketahanan terhadap efek interferensi, derau dan fading, serta kemudahannya untuk dilakukan proses perbaikan (recovery) terhadap sinyal yang rusak akibat proses pengiriman/transmisi sinyal. Kemudian, TV digital menyajikan gambar dan suara yang jauh lebih stabil dan resolusi lebih tajam ketimbang analog serta ketahanan terhadap perubahan lingkungan yang terjadi karena pergerakan pesawat penerima (untuk penerimaan mobile), misalnya di kendaraan yang bergerak, sehingga tidak terjadi gambar bergoyang atau berubahubah kualitasnya seperti pada TV analog saat ini (Dharmanto, 2008). Langkah ini jelas akan menjadi lokomotif bagi perubahan yang cukup radikal di bidang penyiaran televisi nasional serta menjadi era baru bagi dunia industri televisi nasional, menggantikan era penyiaran televisi analog yang dimulai pada 17 Agustus 1962 berupa siaran percobaan TVRI dalam acara HUT Proklamasi Kemerdekaan XVII Indonesia dari halaman Istana Merdeka Jakarta. Pada 24 Agustus 1962, TVRI mengudara pertama kalinya dengan acara siaran langsung upacara pembukaan Asian Games IV dari Stadion Utama Gelora Bung Karno.

2. Implementasi sistem TV Digital di Eropa, Amerika, dan Jepang sudah dimulai beberapa tahun lalu. Di Jerman, proyek ini telah dimulai sejak tahun 2003 untuk kota Berlin dan tahun 2005 untuk Muenchen dan saat ini hampir semua kota besar di Jerman sudah bersiaran TV digital. Belanda telah memutuskan untuk melakukan switch off (penghentian total) siaran TV analognya sejak akhir 2007. Perancis akan menerapkan hal sama pada tahun 2010. Inggris sejak akhir 2005 telah melakukan uji coba mematikan beberapa siaran analog untuk menguji penghentian total sistem analog bisa dilakukan pada tahun 2012. Kongres Amerika Serikat telah memberikan mandat untuk menghentikan siaran TV analog secara total pada 2009, begitu pula Jepang pada 2011. Negara-negara di kawasan Asia juga sudah mulai melakukan migrasi total. Di Singapura, TV digital diluncurkan sejak Agustus 2004 dan saat ini telah dinikmati lebih kurang 250.000 rumah. Di Malaysia, uji coba siaran TV digital juga sudah dirintis sejak 1998 dengan dukungan dana sangat besar dari pemerintah dan saat ini siarannya sudah bisa dinikmati lebih dari 2 juta rumah (Dharmanto, 2008). 
Pemerintah Indonesia telah memutuskan bahwa implementasi sistem TV digital menggunakan sistem Digital Video Broadcasting-Terrestrial (DVB-T) sebagai standar nasional Indonesia. Sementara industri radio, karena teknologi FM radio dianggap sudah cukup memiliki kualitas dan efisiensi yang baik. Teknologi radio FM tetap akan bertahan sampai belasan tahun ke depan. Sehingga penggunaan teknologi $D A B$ (Digital Audio Broadcasting) yang dikembangkan lebih merupakan penyeimbang teknologi DVB-T sebagaimana sudah diimplementasikan di lebih dari 40 negara, khususnya negara-negara Eropa. Teknologi DAB bila dikembangkan menggunakan teknologi Digital Multimedia Broadcasting (DMB), yaitu dengan menambahkan DMB multimedia prosesor, akan mampu menyiarkan konten gambar bergerak sebagaimana siaran TV. Hal ini telah menstimulasi para pelaku industri radio untuk mengembangkan bisnisnya dengan menambah konten berupa gambar bergerak, seperti informasi cuaca, peta jalan, video clip, dan film, sebagaimana yang terjadi di industri televisi.

Mengambil konsep dari Mc Luhan (1997: 7) dimana medium is the message, maka bila diaplikasikan pada internet ${ }^{3}$ atau bentuk World Wide Web (WWW) bisa berupa situs berita online. Dimana analogi dari pernyataan McLuhan dengan melihat perkembangan kemajuan bidang teknologi informasi, maka technology is the message. Teknologi itulah yang menghasilkan medium baru atau melahirkan the new media. Jadi bukan bermaksud untuk melebih-lebihkan pengaruh media. Tetapi, adanya kemajuan teknologi, media menjadi sangat maju - selanjutnya dalam konteks ini penulis menyebut Teknologi Informasi dan Komunikasi -. Media telah berubah menjadi subyek komunikasi yang interaktif dan menjadi sahabat baru manusia. Pola interaksi sosial yang terbentuk melalui media telah menciptakan ruang baru bagi kehidupan manusia. Ruang dimana manusia bisa berimajinasi dan berinteraksi. Sementara apabila dikaitkan dalam konteks media jaringan (komputer) yang kemudian melahirkan cybercommunity (komunitas cyber) juga turut andil dalam membentuk suatu pola hubungan sosial yang tanpa batas, sangat luas dan transparan (Bungin, 2002)

Pengalaman empiris menunjukkan, setiap medium baru berpengaruh terhadap media yang ada. Misalnya, sejak munculnya televisi iklim persaingan semakin kentara. Televisi mempengaruhi eksistensi media cetak dalam hal isi, bentuk, distribusi, kebijakan harga, periklanan dan sebagainya. Karenanya, setiap kali muncul media baru, kata kunci untuk media yang sudah eksis dan ingin tetap eksis adalah adaptasi, inovasi, kreatifitas, atau ketinggalan dan ditinggalkan (Oetama, 2001 : 361). Dengan melihat kondisi masyarakat yang semakin maju, pintar, kritis, dan bebas menentukan sumber-sumber informasinya, terutama di kota-kota besar, maka proses metamorfose media konvensional ke media digital memberikan andil yang cukup besar bagi proses eksistensi media tsb.

Disisi lain, munculnya medium baru tidak berarti meniadakan medium lama. Antara medium lama dan medium baru terjadi proses saling melengkapi, saling mempengaruhi, saling memperkaya inovasi dan kreatifitas. Sehingga setiap kejadian yang diberitakan menjadi lebih jelas maknanya, korelasinya dan interaksinya bagi konsumen (pembaca). Surat-kabar dan majalah menjadi lebih menarik apabila juga

3 Internet secara sederhana menggambarkan kumpulan jaringan yang menghubungkan komputer dan server secara bersamaan (Lister, 2003 : 165) 
mampu menghadirkan edisi online dengan tingkat keterbaruan berita atas peristiwa terakhir, disamping edisi cetak yang menjadi andalannya. Dalam konteks di Indonesia, ketika muncul televisi swasta, media cetak gelisah soal tersedotnya porsi pembagian iklan, orang pers juga meratapi soal penurunan tiras, dan miskinnya minat baca. Akan tetapi, ketika muncul Internet di Indonesia (tahun 1995 dan booming dot com tahun 1998-2000), reaksinya berbeda-beda. Ada surat kabar yang justru melakukan sinergi, sehingga menjadi kekuatan, yakni dengan cara membuka surat kabar edisi cetak online dan edisi realtime news. Fenomena ini berkembang di Indonesia sejak era reformasi 1998 sampai sekarang seiring dengan kemajuan teknologi komunikasi. Sejarah mencatat bahwa suratkabar online pertama yang menghadirkan berita digital adalah Chicago Tribune dalam tahun 1992.

Jumlah pengakses internet di Indonesia dari tahun ke tahun sejak 1998 selalu mengalami peningkatan. Menurut Perkiraan resmi dari Asosiasi Penyelenggara Jasa Internet Indonesia (APJII) terhadap jumlah pelanggan dan pemakai internet selama ini dan perkiraan sampai akhir tahun 2007 adalah sesuai dengan tabel berikut ini:

Tabel 1. Perkembangan Jumlah Pelanggan \& Pemakai Internet (kumulatif) perkiraan s/d akhir 2007

\begin{tabular}{ccc}
\hline Tahun & Pelanggan & Pemakai \\
\hline 2007 & 2.000 .000 & 25.000 .000 \\
2006 & 1.700 .000 & 20.000 .000 \\
2005 & 1.500 .000 & 16.000 .000 \\
2004 & 1.087 .428 & 11.226 .143 \\
2003 & 865.706 & 8.080 .534 \\
2002 & 667.002 & 4.500 .000 \\
2001 & 581.000 & 4.200 .000 \\
2000 & 400.000 & 1.900 .000 \\
1999 & 256.000 & 1.000 .000 \\
1998 & 134.000 & 512.000 \\
\hline
\end{tabular}

Sumber: APJII

Internet mampu memberikan layanan kecepatan informasi setiap saat, detail dan bebas biaya. Sehingga tidak lah mengherankan apabila terjadi kenaikan jumlah pengakses internet setiap tahunnya di Indonesia. Fenomena umum orang online ke internet adalah untuk mendapatkan informasi dan berbagi informasi. Barangkali masih ingat fenomena berita bawah tanah mailing list apa kabar di internet (19951997) yang sempat populer dengan analisis permasalahan seputar ekonomi dan politik Indonesia waktu itu, namun identitas nara sumber seringkali disembunyikan. Fenomena lain dengan adanya peniadaan Surat Ijin Usaha Penerbitan Pers (SIUPP), ketika era Presiden BJ. Habibie dan Menteri Penerangan Yunus Yosfiah (1999) yang berakibat kebebasan pers (kemudahan mendirikan media) tidak terkecuali sampai pers online atau menyinergikan dengan online. Fenomena internet dot com dengan $e$ commerce dan web $2.0^{4}$ memberikan andil pada perkembangan sejarah media di

${ }^{4}$ The term 'Web 2.0' was introduced as a new concept at a conference brainstorming session between Tim O'Reilly and MediaLive in 2001. In this initial discussion the concepts were 
Indonesia, sampai memasuki era media-media alternatif digital seperti blog, friendsters, facebook, $i P o d$, iPhone $3 G$, dan sebagainya.

Menurut Daniel Dhakidae (Kompas, 28 Juni 2005) surat kabar generasi modern industrial bersaing dengan televisi tentang seberapa cepat menyajikan kejutan berita yang disebut scoop. Surat kabar generasi post-modern harus bersaing bukan sekadar dengan televisi, tetapi televisi yang sudah mengalami "transformasi" oleh seluruh teknologi digital yang memungkinkan multimedia, dengan internet sebagai pusatnya, di mana setiap orang bisa serentak mendengar, melihat, membaca sesuatu yang berasal dari aneka sumber pada saat yang hampir bersamaan. Secara tidak sadar para pembaca modern surat kabar cetak mengalihkan kebiasaan quick browsing internet ke dalam cara membaca surat kabar.

Disisi lain di Amerika Serikat (AS) terdapat fenomena surat kabar cetak memasuki era digital ini menghadapi tantangan berat seperti penurunan sirkulasi, penurunan jumlah pembaca dan pemasukan iklan, serta kompetisi yang sengit dari kompetitor digital. Sehingga beberapa surat kabar terkemuka AS mengakhiri edisi cetak dan berpindah ke edisi online. Seperti diberitakan Kompas 27 Maret 2009 (hal,10), The Christian Science Monitor (CSM)5 yang bermarkas di Boston, Massachusetts dan berusia 100 tahun menerbitkan edisi terakhir surat kabar pada Kamis 26 Maret 2009. Sirkulasi CSM merosot menjadi sekitar 50.000 eksemplar, rugi 18,9 juta dollar AS pada tahun anggaran yang berakhir April 2009 dan membutuhkan subsidi hingga 12,1 juta dollar. Penghentian edisi cetak surat kabar CSM, hanya berselang dua pekan setelah surat kabar besar AS lainnya, Seattle Post-Intelligencer yang telah terbit selama 146 tahun. Surat kabar Rocky Mountain News tutup pada Februari 2009. Sejumlah kelompok surat kabar lain, seperti Tribune Co, pemilik Los Angeles Times dan Chicago Tribune, telah mengajukan proses kebangkrutan demi menyiasati kerugian selama bertahun-tahun.

Fenomena pengaruh internet pada media cetak tsb tidak bisa dicegah, dan sedapat mungkin bersinergi dengan format internet. Walaupun internet dapat meningkatkan risiko informasi, aksesibilitas yang bebas, interaktivitas, globalitas, konektivitas komunikasi personal, ekonomis dan politik, serta hilangnya kontrol jurnalistik atas pasar informasi. Namun, dengan edisi online internet mampu menjangkau jumlah pengunjung situs yang lebih besar. Sejauh pengamatan penulis, sinergi media cetak dengan internet memperkuat penentuan diri khalayak dalam hal informasi dan membuat mereka lebih bebas dari media konvensional. Internet sebagai media teknologi baru juga mempengaruhi transformasi jurnalisme secara fundamental (Pavlik, 2001). Seperti serba berita (ubiquitous news), akses informasi global, peliputan saat itu juga (instantaneous reporting), interaktif, wujud isi aneka

exemplified by sites such as Flickr, Wikipedia and the blogosphere in general, where content is added and maintained by site visitors. This contrasts with the traditional 'Web 1.0' model where content is published by site owners in a 'read only' state and is merely consumed by site visitors.

${ }^{5}$ CSM didirikan tahun 1908 oleh Mary Baker Eddy, pendiri Gereja Kristen Sains. Diterbitkan setiap hari Senin-Jumat, meliputi berita-berita internasional dan lokal AS. CSM telah memenangi tujuh penghargaan jurnalistik Pulitzer, terakhir tahun 2002. CSM terkenal karena liputan mendalam soal Timur Tengah dengan memublikasikan hasil liputan wartawan spesialis Timur Tengah, seperti mendiang John K. Cooley (sumber : Kompas 27 Maret 2009) 
media (multimedia content), serta penyediaan isi yang luar biasa spesifik (extreme content customization).

Tahapan perkembangan isi berita dalam edisi online internet menurut Pavlik (1998) telah melewati tiga tahap yaitu: (a) surat kabar online hanya memindahkan ulang versi cetaknya ke online (repurpose content from their mother ship); (b) surat kabar sudah membuat isi inovatif-kreatif dalam websitenya dengan fitur interaktif seperti hyperlinks dan search engines, yang dapat memudahkan pengguna mencari materi dengan topik-topik khusus yang sesuai dengan ukuran kebutuhannya, misalnya dengan katagori berita dan informasi yang dipilihnya (the journalists create original content and augment it with such additives as hyperlinks - with which a reader can instantly access another website; interactive features such as search engines, which seek out material on specific topics; and a degree of customization - the ability to choose what categories of news and information you receive); dan (c) isi berita telah didesain secara khusus untuk media web sebagai sebuah medium komunikasi (original news content designed specifically for the Web as a new medium of communication).

\section{Pokok Permasalahan}

Dari fenomena media cetak yang mengalami perubahan karena pengaruh internet serta bersinergi antar keduanya, inilah permasalahan yang menarik dalam kaitannya dengan hypertext ${ }^{6}$ yang berdampak pada newsroom dan kinerja jurnalis untuk semua tipe media (tv, radio, cetak) dalam batasan computer assisted reporting $(C A R)$ dalam era konvergensi media.

\section{PEMBAHASAN}

\section{Internet sebagai Medium Jurnalistik}

Marshall McLuhan (1999 : 7) dalam bukunya, Understanding Media - The Extensions of Man menyatakan bahwa, the medium is the message. Bahwa medium yang dipakai untuk menyampaikan informasi dan pesan, membentuk format pesan itu sendiri. McLuhan menganggap media sebagai perluasan manusia. Media yang berbeda-beda mewakili pesan yang berbeda-beda. Media menciptakan dan mempengaruhi cakupan serta bentuk dari hubungan-hubungan dan kegiatankegiatan manusia. Pengaruh media dengan adanya kemajuan teknologi menjadi sangat dahsyat bagi umat manusia. Media telah campur tangan dalam kehidupan manusia secara lebih cepat daripada sebelumnya, juga memperpendek jarak diantara bangsa-bangsa. Media massa apapun bentuknya akan selalu membawa pesan tersendiri bagi masyarakatnya.

Munculnya perdebatan yang problematik atas internet sebagai medium apakah sebagai media massa atau media komunikasi antarpersona lebih disebabkan oleh sifat internet itu sendiri, yang bisa diklasifikasikan ke dalam media massa atau media konvensional yang individual dan antarpersona. Internet bisa dikatakan sebagai

${ }^{6}$ Hypertext/ hypermedia : text and other contents edited and to be recieved and read in a nonlinear way, jumping from one source, page, image, etc to another; typical way to design and consume multimedia content (Dijk.2006:266). 
sebuah hybrid (perkawinan) yang mana keduanya mampu bekerja sebagai perangkat CD player dan televisi. Internet juga sebagai medium komunikasi antarpersona, contohnya e-mail. Jensen (1998 : 46) memisahkan berbagai macam media, yang kemudian disebut media "pull' dan "push". Media tradisional, seperti TV, radio, dan film, mempunyai karakteristik "push", dimana isi media diciptakan oleh medianya untuk pembaca, pendengar dan pemirsanya. Sedangkan dalam "pull" media (internet) isinya diciptakan oleh pengguna. Audience perannya lebih aktif ketika surfing on the net daripada ketika surfing saluran TV. Isi media bergeser dari seragam ke personal, dan siklus publikasi berkembang dari periodik menuju up to date.

Munculnya medium baru internet, yang salah satu fasilitasnya populer dengan nama World Wide Web (WWW) era 1990-an, menandakan babak baru dalam sistem komunikasi global. Sistem komunikasi tanpa batas. Melampaui batas-batas fisik geografis, mental ideologis, ruang dan waktu. Komputer yang sebelumnya sebagai medium pengumpulan dan penyimpanan, berkembang menjadi media komunikasi dan jaringan komunikasi yang kompleks dengan segala struktur operasionalnya. Dengan membawa konsekuensi-konsekuensi tersendiri bagi relasi pribadi dan sosial. Sehingga pada akhirnya Internet membawa bentuk budaya media. Dalam Internet, interaksi antara orang-orang dimediasi oleh komputer, dan ditentukan oleh alat teknologi yang dipergunakan. Interaksi komunikasi yang terjadi bukanlah sesuatu yang lahir secara natural. Melainkan hasil adanya konstruksi teknologi.

Jurnalistik sebagai kegiatan melaporkan berbagai kejadian atau peristiwa yang terjadi di masyarakat, tidak lepas dari konstruksi dengan perspektif tertentu untuk dijadikan bahan berita oleh jurnalis. Sementara berita adalah laporan atau pemberitahuan tentang sesuatu kejadian atau peristiwa yang disampaikan melalui orang lain, baik secara lisan maupun tertulis (Peter dan Salim, 1991). Dalam konteks ini, pengertian berita (news) yang dimaksud adalah penyajian informasi yang sudah, sedang dan akan terjadi.

Secara umum media mempunyai tujuan agar khalayaknya mempelajari peristiwa, tetapi media tidak berusaha mengajar orang-orang tentang hal-hal yang ada dalam berita. (McQuail: 1987; 246) Pertanyaan yang menarik adalah seberapa jauh orang memahami dan mengingat berita?. Ini lah yang menarik dalam teori difusi berita, yaitu penyebaran berita yang diukur berdasarkan kemampuan mengingat peristiwa tertentu. Variabel penting yang menjadi pusat perhatiannya adalah; sejauh mana orang-orang mengenal peristiwa tertentu; kadar penting atau kemenonjolan yang relatif dari peristiwa bersangkutan; volume informasi yang disampaikan tentang peristiwa itu; sejauh mana informasi tentang suatu peristiwa diperoleh pertama kali dari berita; seberapa cepat media memberikan dan menyebarkan informasi. (McQuail: 1987; 246).

Impelmentasi teori tsb, penulis mencoba melihat kondisi saat ini dimana perkembangan teknologi informasi dan komunikasi, mengakibatkan adanya tuntutan perubahan bentuk berita, dari pers cetak dan broadcast menjadi bentuk berita online (e-News). Berita dalam media online berkembang sangat pesat, tidak saja dalam bentuk teks tetapi juga dalam bentuk multimedia, yaitu menggabungkan teks, audio dan video yang bisa diakses kapan pun dan di mana pun manusia berada. Sehingga menurut Fidler (1997) multimedia sering disebutnya sebagai mixed media. Sementara media konvensional (tv, radio, media cetak) yang telah melakukan sinergi dengan 
internet di era konvergensi ${ }^{7}$ media mampu meningkatkan value added dan brand yang semakin kuat dan luas. Ukuran audience proximity secara geografis yang menjadi keunggulan (media cetak, radio, tv lokal) selama ini menjadi semakin absurd pada media online. Melalui webcasting dalam media online mampu mendekatkan secara emosional seseorang terhadap daerah asal atau kelahirannya, seperti seorang yang sedang berada di luar negeri karena studi, bekerja, atau telah menjadi warga negara asing.

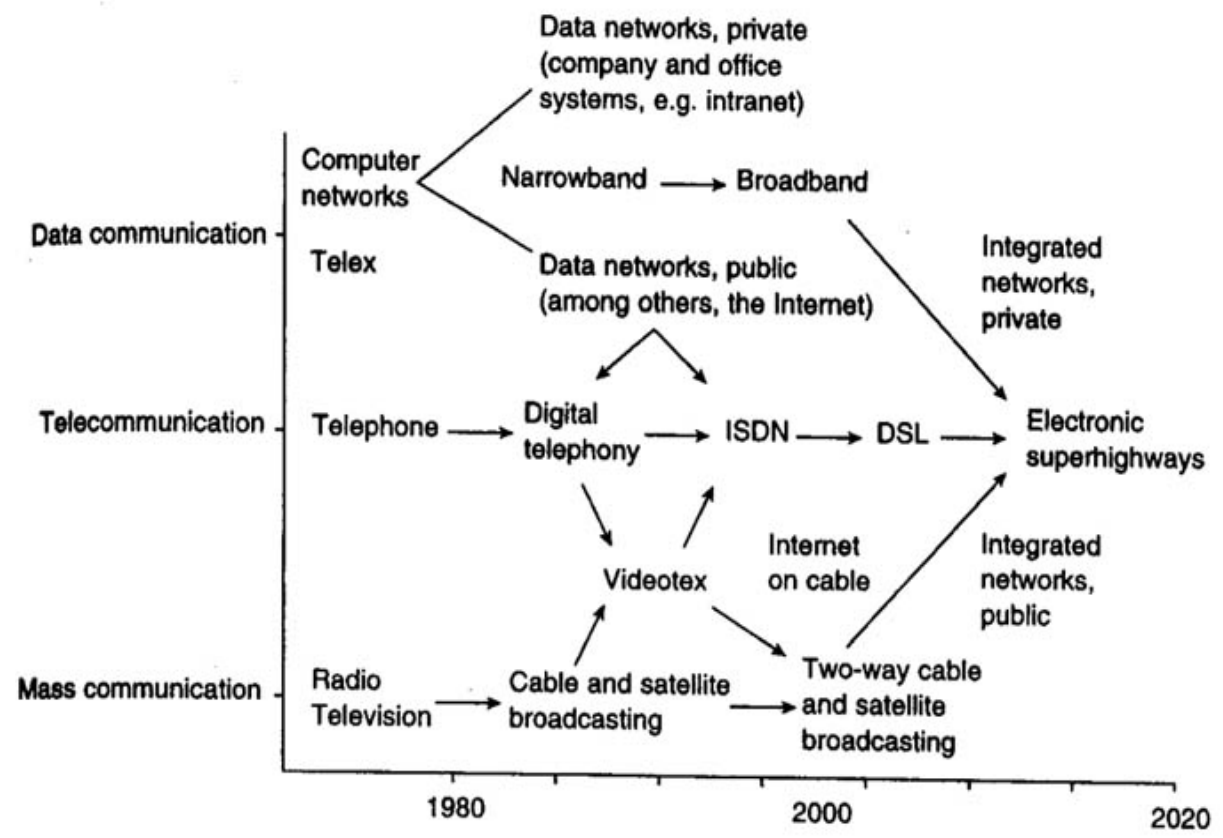

Sumber : Dijk, 2006:7

\section{Gambar 1. Integrasi Transmisi dalam Bidang Komunikasi}

Proses konvergensi menuju integrasi bisa masuk dalam salah satu level berikut: 1) infrastruktur - sebagai contoh kombinasi hubungan transmisi yang berbeda dan peralatan untuk telefon dan komunikasi data komputer; 2) transportasi - sebagai contoh telefoni internet and web TV bergantung pada kabel dan televisi satelit; 3) manajemen - sebagai contoh perusahaan kabel mengembangkan/ menggunakan saluran telefon dan perusahaan telefon mengembangkan televisi kabel; 4) layanan sebagai contoh kombinasi dari informasi dan layanan komunikasi pada internet; 5) jenis data - menaruh data jenis suara, teks, dan gambar secara bersama. Dalam gambar tsb bagaimana jaringan publik dan privat data, tele- dan komunikasi massa secara bersama-sama menciptakan jaringan multifungsional berkecepatan tinggi yang disebut electronic superhighway dalam tahun 1990-an, tetapi saat ini biasa disebut broadband (networks).

${ }^{7}$ Karakteristik media baru secara struktural adalah integrasi telekomunikasi, komunikasi data, dan komunikasi massa dalam satu medium. Sehingga menjadi satu medium merupakan proses yang disebutnya konvergensi. Karena alasana inilah new media sering disebut multimedia (Dijk.2006 : 7). 
Disamping itu, informasi yang disajikan medium internet sebagai sumber informasi sama dengan medium lain, bahkan lebih unggul dari unsur kecepatan, seketika, interaktifitas, hyperlinks text sebagai sumber informasi dan tidak tergantung pada jadwal siar dan periodesitas seperti dijumpai pada surat kabar (terbit pagi atau sore). Bahkan menurut penulis media online di Indonesia yang berbasis pada lembaga yang sudah mapan sudah menunjukkan kemajuan yang sangat luar biasa, tidak sekedar cetak yang dionlinekan, namun isi berita telah didesain secara khusus untuk media web sebagai sebuah medium komunikasi, seperti apa yang dikatakan Pavlik (1998). Situs berita sebagai nara sumber bukan lagi bersifat komplementer namun bersinergi dengan isi siaran, telekomunikasi (infrastruktur dan jaringan), dan komputer sehingga mampu menghadirkan jurnalisme online dengan perspektif multimedia. Sebuah revolusi media yang demikian maju.

Hasil wawancara penulis dengan pengelola media online Suara Surabaya.net menyatakan bahwa mereka mengembangkan radio internet dan jurnalistik online sekaligus karena tuntutan perkembangan. Media harus tetap dekat kepada audience nya dimana pun mereka berada. Informasi audio dan video dapat disimpan dalam bentuk digital dan memudahkan pendengar untuk menelusurnya kembali (archive file). Radio sudah tidak bisa dibatasi jangkauannya secara geografis dan frekuensi. Radio harus go online untuk menambah value added dan menambah kekuatan brand melalui berita-beritanya yang seketika. Sementara menurut Pemimpin Redaksi Harian Surya diperoleh informasi bahwa mereka mendesain situsnya agar unsur efektifitas dan efisiensi lebih baik secara manajemen. Serta sedang mengembangkan edisi online multimedia. Sedangkan bagi informan yang berada di luar negeri diperoleh informasi bahwa faktor-faktor seseorang mengakses situs berita Indonesia karena ada unsur emosional dengan tanah kelahiran, ingin mengetahui secara persis dan aktual kejadian Politik, Ekonomi Sosial dan Budaya di Indonesia, yang mustahil mereka dapat melalui medium konvensional. Serta untuk saling bertukar informasi dan kabar berita dengan rekan, famili dan keluarga.

Berita realtime (seketika) yang nota bene berkembang pesat era 1990-an ternyata secara radikal mempengaruhi industri penerbitan pers cetak, dan mampu menaklukan ruang dan waktu yang selama ini dihadapi pers cetak. Proses gathering information lewat internet berlangsung melalui information brokers (perantara), tidak lewat penerbitan pers, sehingga menjadi lebih singkat dan seketika. Berita elektronik dapat ditampilkan (upload) dan diperbarui (update) dalam hitungan menit bahkan detik. Sedangkan berita konvensional, khusus media cetak, membutuhkan waktu sedikitnya satu hari untuk proses gathering information (peliputan), layout, dan cetak. Dalam berita elektronik, cenderung menampilkan berita straight news, breaking news, singkat dan padat. Namun terus menerus diperbarui.

\section{Hypertext Dalam Jurnalistik Online}

Menurut Lister ( 2003 : 23), kata 'hype' dalam hypertext adalah sebuah kata kunci yang merujuk kepada inovasi dari media baru (new media) dan yang membedakan dari 'old analogue media'. Sedangkan awalan 'hyper' dikembangkan dari bahasa Yunani yang artinya di atas (above), di seberang (beyond), atau di luar (outside). Jadi berdasarkan asal katanya, maka hypertext hadir untuk menjelaskan sebuah teks yang 
memberikan sebuah sistem hubungan kepada teks lain yang berada 'di luar', 'di atas', dan 'di seberang' teks itu sendiri.

Roland Barthes menggambarkan sebuah teks ideal yang sesuai dengan jaman, karena adanya perkembangan teknologi khusunya komputer, adalah dengan hypertext yaitu teks tersusun atas kata dan gambar yang terhubung (linked) secara elektronik dengan banyak bagian/folder (paths). Dimana kemudian disebut lexia, sebuah elektronik links yang saling berhubungan. Terms (hypertext) ini kemudian disebut link, node, network, web, dan path. Sama dengan Barthes, Michel Foucault juga mempunyai pendapat atas teks dalam terms network (jaringan) dan links. Sehingga kemudian, melahirkan apa yang disebutnya hypermedia sebagai kepanjangan atas teks dalam hypertext yang di dalamnya terdapat informasi visual, suara, animasi, dan bentuk-bentuk data lainnya. Sejak keberhasilan hypertext mampu menghubungkan teks seperti gambar, peta, diagram, dan suara semudah menyampaikan pesan verbal lainnya, hypertext kemudian menjadi hypermedia. Hypertext menjadi medium informasi yang menghubungkan pesan verbal dan non verbal. Antara hypertext dan hypermedia mampu bertukar peran (Landow, George, The Definition of Hypertext and Its History as a Concept)

Internet, sebagai sebuah jaringan komputer global, merupakan suatu teknologi yang memicu perkembangan berita elektronik (E-News). Teknologi internet memungkinkan berita (News) dipublikasikan dengan menggunakan format Hypertext MarkUp Language (HTML) 8. Dimana, format berita (teks, gambar/foto, video, audio, animasi) disajikan secara digital, sehingga pembaca dapat mengakses dari komputer dengan cepat dan seketika pada halaman web (web pages). Jarak dan waktu bukan lagi kendala. Karenanya, internet sebagai medium jurnalistik memiliki banyak kelebihan dibandingkan media massa lain. Mudah mengaksesnya, memproduksi dan menyebarkan dengan cepat dan murah dengan daya jangkau dunia. Seperti produk dan layanan yang sudah dikembangkan BBC (bbc.co.uk) antara lain news feed, podcasts $^{10}$, deskstop alert ${ }^{11}$, berita pada mobile phones, Portable Digital Assistant (PDA), serta perangkat mobile lainnya.

Sebuah dokumen bisa merupakan informasi. Sebuah artikel di surat-kabar adalah dokumen (dokumen cetak), demikian halnya dengan paket acara TV, sebuah

\footnotetext{
${ }^{8}$ HTML adalah tag atau kode yang dapat menampilkan teks dan layout graphic yang kemudian dikenal sebagai web pages. Dalam file HTML terdapat tag atau kode yang dimengerti oleh web browser dan dapat menampilkan dokumen pada layar monitor komputer. Dalam tag HTML ditandai dengan karakter "<" atau ">", dan umumnya tag HTML dibuat berpasangan, ada tag pembuka dan ada tag penutup. Format umum tag HTML adalah <nama_tag> Teks yang akan ditampilkan </nama_tag>. HTML dikembangkan oleh Tim Berners-Lee dalam awal tahun 1990an.

${ }^{9}$ Fasilitas news feed bagi user/ audience memudahkan mendapatkan headline dan video terkini tanpa harus mengunjungi website. Newsfeed merupakan halaman web yang didesain untuk dibaca oleh komputer daripada oleh user.

10 Fasilitas podcasting secara otomatis bisa menerima episode terkini atas pilihan pendengar untuk program acara tertentu di radio. Audio podcasts memudahkan pendengar radio untuk mendengarkan program radio favorit secara mobile dimana pun dan kapan pun berada dengan cara subscribe dan instal software di komputer dan perangkat portabel seperti mp3 player.

${ }^{11}$ Fasilitas deskstop alert memudahkan user/ audience menerima headline berita terkini yang dikirimkan langsung dari media ke komputer deskstop.
} 
lagu atau video juga merupakan dokumen (dokumen elektronik). Jadi bagi seorang reporter dalam era digital akan dihadapkan pada terminologi baru yang berubah yaitu dokumen. Ketika reporter dan editor membuat sebuah dokumen news untuk masing-masing media dimana mereka bekerja, mungkin mereka juga akan berpikir format dokumen yang sesuai, entah itu cetak atau elektronik. Dokumen elektronik yang nota bene berisi informasi dapat diubah dari format analog ke format digital. Teknologi internet memungkinkan hal ini. Dimana, dengan format digital dokumen dapat diakses lewat internet, termasuk gambar/ foto, audio, video, instruksi pemrograman web interaktif, dan animasi. Yang semua ini bisa diakses lewat browser internet. Jadi kesimpulannya hypertext bisa dikatakan sebagai jantungnya online news.

Perkembangan online news akan memaksa reporter media cetak mengadopsi gaya broadcast, dimana dalam dunia broadcast seorang reporter menulis untuk video, still images dan suara. Sehingga pemirsa bisa mendengar dari radio maupun melihat dari layar kaca televisi. Kata dalam broadcast mampu melengkapi teka-teki informasi dalam benak pikiran pemirsa atau pendengar. Reporter media cetak sebaliknya, harus menggunakan bahasa agar pesannya sampai pada benak pikiran pembacanya seperti apa yang dilihat dilayar televisi. Karenanya, seorang reporter media cetak mencoba membuat sebuah "layar" dalam benak pikiran pembacanya, dengan membangun daya ingat dan imajinasi pembaca.

Seperti halnya dengan reporter broadcast tersebut, reporter untuk media web juga telah menambahkan teks elektronik (e-texts) dalam cara kerja mereka. Teks elektronik termasuk didalamnya video dan still images, animasi, suara, dan tentu saja kata. Karenanya, tantangan sebagai reporter media web adalah mampu memberikan perspektif baru agar berita menjadi benar-benar kredibel dan bisa dipercaya masyarakat. Sehingga persepsi masyarakat yang masih menganggap berita dari media web sebagai sumber berita komplementer dapat diubah dengan menerapkan kinerja profesional, sebagai sumber berita cepat dan seketika.

Fasilitas radio on demand merupakan dokumentasi audio clip dengan durasi tertentu, video on demand merupakan visual clip berita hasil liputan reporter. Video on demand biasanya berupa file moviel film yang bisa diakses oleh netter kapan saja yang tampilannya berupa gambar bergerak dengan disertai audio yang langsung diambil dari tempat kejadian. Pada saat download video on demand durasi waktu yang dibutuhkan antara satu sampai dengan dua menit, dengan besar file berkisar antara 500 - 1000 kilobyte. Termasuk Wireless Application Protocol (WAP) yang merupakan fasilitas aplikasi nirkabel yang memungkinkan pendengar untuk selalu mendapatkan informasi yang diinginkan dimana pun dan kapan pun kita berada melalui telepon genggam (telepon selular/ ponsel).

\section{Fleksibilitas, Kapasitas, Immediacy, dan Permanen}

Esensi dari Worl Wide Web dalam penjelasan sebelumnya adalah berita, dimana pembaca membacanya melalui sebuah browser. Menurut James Glen Stovall (2004) pada online journalism dikenal dimensi fleksibilitas, kapasitas, immediacy dan pemanen. Para reporter dapat memasukan laporan berita mereka dengan berbagai bentuk untuk informasinya, baik secara full text, disertai informasi biografi sumber, 
diagram, peta, dan gambar yang dapat membantu pembaca mengerti subyek pemberitaannya. Bahkan dapat memasukan audio dari sumber dan video scenes dimana berita diambil. Inilah fleksibilitas media internet dari pada cetak atau penyiaran. Namun, dalam online journalism juga terdapat batasan yang terletak pada komputer server secara kuota atau ruang data dimana informasi tersebut disimpan dan lamanya waktu akses. Inilah yang disebut sebagai batasan kapasitas.

Online journalism dapat mengirim berita secara seketika dan serentak (instantaneous reporting) dalam bentuk breaking news event sesuai konteksnya dengan cakupan coverage yang global. Sesuatu yang dirasa sulit bagi para broadcaster untuk memberikan informasi berita breaking news mereka. Inilah yang disebut sebagai immediacy. Sedangkan, online journalism disebut permanen karena para reporter bekerja berjam-jam untuk sebuah dokumen berita secara digital yang dapat disimpan dalam sebuah server komputer dalam waktu lama dan terjaga kualitasnya. Berbeda dengan surat kabar yang mediumnya kertas akan mudah pudar dan sobek, demikian juga medium videotape dan audiotape kualitasnya akan menurun seiring waktu yang terus bergulir. Informasi yang tersimpan online kualitasnya begitu powerfull, mudah ditelusur ulang (retrievability) namun juga rawan diduplikasi. Karena the web adalah sebuah medium terbuka dan sarat teknologi secara berjaringan, sehingga mudah diduplikasi dan disimpan dalam lokasi yang berbeda dari aslinya.

\section{Interaktifitas dalam media online}

Semua media tentunya interaktif. Pemirsa televisi dan pendengar radio harus menyalakan pesawatnya dan memilih gelombang dan salurannya (channel). Dengan remote control memberikan pengguna bebas untuk memilih channel. Tetapi media ini tidak menawarkan kesempatan untuk berinteraksi. Media televisi dan radio tidak mempunyai pilihan dan mekanisme feedback ketika programnya disiarkan. Kecuali adanya kontribusi medium e-mail dan telephone. Sedangkan suratkabar dan majalah dinilai lebih interaktif karena pembaca dapat memilih bagian apa yang lebih suka dibaca dan bagian mana yang diabaikan. Headlines (teks yang mengarahkan pembaca kepada topik atau judul besar liputan), layouts dan index mampu memberikan pembaca pilihan. Tetapi media cetak tidak menawarkan melalui saluran apa pembaca dapat merespon apa yang mereka lihat dan berinteraksi dengan reporter yang memproduksi berita. Kecuali adanya kontribusi dari medium surat pembaca atau telephone.

Interaktivitas dalam online journalism adalah adanya sebuah hubungan antara reporter dengan pembacanya (consumer) dan hubungan yang bermakna dengan sebuah bentuk baru jurnalistik. Menurut Williams, Rice, dan Rogers 1998 (dalam Severin and Tankard, 2001: 370) mendefinisikan interaktifitas sebagai "the degree to which participants in a communications process have control over, and can exchange roles in, their mutual discourse". Jadi kontrol komunikasi internet ada pada pengguna. Salah satu studi penggunaan internet mendapatkan enam dimensi interaktifitas yaitu (1) internet mampu memberikan informasi dari pada sekedar persuasi; (2) kontrol terletak pada pengguna internet; (3) aktifitas banyak dilakukan oleh pengguna (aktif); (4) komunikasi yang terjadi dua arah; (5) waktu yang digunakan dalam komunikasi lebih fleksibel dari pada terjadwal (periodisasi seperti dalam media 
cetak), dan (6) komunikasi berlangsung pada suatu tempat yang 'diciptakan' oleh para consumer (Rogers, 1998). Berikut adalah analisis fitur-fitur yang ada dalam online media.

Tabel 2 . Analisis Fitur dalam Media Online

\begin{tabular}{|c|c|c|c|c|c|}
\hline Fitur & Hypertext & Multimedia & Arsip & Interaktif & Virtual \\
\hline $\begin{array}{l}\text { Aplikasi } \\
\text { Media } \\
\text { Tradisional }\end{array}$ & $\begin{array}{l}\text { Links berada di } \\
\text { dalam situs } \\
\text { (dari halaman } \\
\text { pertama ke } \\
\text { halaman lain) }\end{array}$ & $\begin{array}{l}\text { - gambar } \\
\text { - video klip } \\
\text { - audio klip }\end{array}$ & $\begin{array}{l}\text { - Arsip surat } \\
\text { kabar } \\
\text { secara full } \\
\text { text } \\
\text { - browsing } \\
\text { dengan } \\
\text { tanggal }\end{array}$ & $\begin{array}{l}\text { mekanisme } \\
\text { feedback dengan } \\
\text { e-mail. } \\
\text { kemungkinan } \\
\text { mengirim } \\
\text { materi ke surat } \\
\text { kabar }\end{array}$ & $\begin{array}{l}\text { Kecepatan } \\
\text { pemutahiran } \\
\text { data (update) } \\
\text { sama seperti } \\
\text { proses yang } \\
\text { terjadi pada } \\
\text { surat kabar }\end{array}$ \\
\hline \multirow[t]{2}{*}{$\begin{array}{l}\text { Aplikasi New } \\
\text { Media }\end{array}$} & $\begin{array}{l}\text { Links ke } \\
\text { halaman web } \\
\text { lain. }\end{array}$ & $\begin{array}{l}\text { Penggabungan } \\
\text { berbagai macam } \\
\text { presentasi }\end{array}$ & Arsip artikel & $\begin{array}{l}\text { Forum diskusi } \\
\text { online }\end{array}$ & $\begin{array}{l}\text { Penerbitan } \\
\text { secara } \\
\text { realtime }\end{array}$ \\
\hline & $\begin{array}{l}\text { Links ke } \\
\text { material arsip } \\
\text { Mengurangi } \\
\text { adanya lubang } \\
\text { berita' }\end{array}$ & Mixed media & $\begin{array}{l}\text { Penelusuran } \\
\text { melalui search } \\
\text { engine } \\
\text { menghasilkan } \\
\text { data secara } \\
\text { full text }\end{array}$ & $\begin{array}{l}\text { Ruang obrolan } \\
\text { (chat rooms) } \\
\text { Online Surveys } \\
\text { Jurnalisme } \\
\text { publik }\end{array}$ & $\begin{array}{l}\text { Intergrasi } \\
\text { layanan berita } \\
\text { secara online } \\
\text { dan offline }\end{array}$ \\
\hline
\end{tabular}

Sumber: Wallenius (2003). News Journalism on the Internet : p. 13

\section{KESIMPULAN}

Dari uraian dalam pembahasan tersebut, maka dapat disimpulkan bahwa perkembangan jurnalistik online di Indonesia tidak terlepas dari perkembangan situasi politik di Indonesia dengan berbagai kebijakan rejim penguasa yang menyertainya. Jurnalistik online periode pertama berkembang mulai 1995 - 1997 dengan ditandai hadirnya internet di Indonesia yang kemudian diterapkan dan kembangkan oleh IPTEKNET, munculnya Internet Service Provider (ISP), web service, fenomena mailing list apakabar yang cukup sensasional waktu itu, yaitu runtuhnya Orde Baru oleh gerakan Reformasi (era reformasi), Tempo Interaktif dan Kompas Cyber Media. Periode kedua mulai 1998 - 2001 ditandai fenomena dotcom dan bergugurannya dotcom, pencabutan Surat Ijin Usaha Penerbitan Pers (SIUPP) oleh Mentrei Penerangan Yunus Yosfiah pada Kabinet Presiden Habibie yang menandakan era kebebasan pers menjadi lebih baik dari sebelumnya, dan jurnalisme online di Indonesia sudah memasuki tahapan periode ketiga seperti apa yang digambarkan oleh pavlik (1998), dimana isi berita telah didesain secara khusus untuk media web sebagai sebuah medium komunikasi.

Dalam periode ketiga, sejak 2002 sampai sekarang adalah fenomena jurnalistik online multimedia atau webcasting dengan produk dan layanan seperti news feed, podcasts, deskstop alert, berita pada mobile phones, PDA ,serta perangkat mobile 
lainnya. Hal ini sebagai akibat perkembangan teknologi informasi dan jaringan (infrastruktur) yang berimbas pada media, yang pada akhirnya menghasilkan konvergensi media (sinergi), dengan tidak mengesampingkan akan adanya kebutuhan akses kebebasan informasi yang cepat, seketika dan transparan, tidak dibatasi ruang dan waktu serta adanya kepercayaan publik itu sendiri pada berita online

\section{DAFTAR PUSTAKA}

Baran, Stanley J. (2003). Mass Communication Theory; Foundations, Ferment, and Future, $3^{\text {rd }}$ edition. Belmon, CA : Thomson

Bungin, Burhan; New Media dan Perkembangannya; Konstruksi Sosial Telematika dan Inovasi Media Baru, Seminar dan Lokakarya "Being Local in National Context : Understanding Local Media and Its Struggle", Universitas Kristen Petra, di Surabaya 14 Oktober 2002.

Dewdney, Andrew., and Ride, Peter. (2006). The New Media Handbook. London. Routledge.

Dharmanto, Satryio Bernadus. (2008). Menyikapi Lahirnya Era Penyiaran TV Digital http://tekno.kompas.com/read/xml/2008/10/23/1600400/ diakses 23 Oktober 2008.

Dijk, Jan Van. (2006). The Network Society; Social Aspects of New Media. $2^{\text {nd }}$ edition. London. SAGE Publications Ltd.

Craig, Richard. (2005). Online Journalism; Reporting, Writing and Editing for New Media: Thomson

Effendy, Onong Uchjana. (2005). Komunikasi dan Modernisasi, Bandung: Mandar Maju

Fidler, Roger. (1997). Mediamorphosis, Understanding New Media. Pine Forge Press, Thousand Oaks (calif),.

Ibrahim, Idi Subandi. (2004). Sirnanya Komunikasi Empatik; Krisis Budaya Komunikasi dalam Masyarakat Kontemporer: Bandung : Pustaka Bani Quraisy.

Jensen, Jens Frederik. (1998). Communication Research after The Mediasaurus? Digital Convergence, Digital Divergence. The Media Lanscape in Transition. Research on New Information Technology. In Nordicom Review 1/98. Nordicom, Goterborgs Universitet.

Landow, George; The Definition of Hypertext and Its History as a Concept, http://www.thecore.nus.edu.sg/landow/cpace/ht/jhup/history.html\#1, diakses 14 Pebruari 2005.

Lister, Martin. (2003). New Media : A Critical Introduction. London : Routledge 
Muljono; Sistem Berita Elektronika di Intranet Universitas Pelita Harapan Menggunakan Lotus Notes dan Domino, Jurnal Ilmiah Universitas Pelita Harapan, LPPM-UPH Menara UPH - Lippo Karawaci - Tangerang.Vol. 4/No.7 Agustus 2001, Hal. 37.

McLuhan, Marshall. (1999). Understanding Media; The Extension of Man. London : Routledge.

McQuail, Denis. (1987). Teori Komunikasi Massa; Suatu Pengantar. Jakarta. Edisi Kedua: Erlangga.

McQuail's, Denis. (2001). Mass Communication Theory. London. $4^{\text {th }}$ edition: SAGE Publications, Inc.

Muslimin, Totok., dan Djuroto. (2002). Teknik Mencari dan Menulis Berita. Semarang: Dahara Prize, Effhar Offset.

Oetama, Jacob. (2001). Pers Indonesia Berkomunikasi dalam Masyarakat Tidak Tulus: Percetakan PT. Gramedia. Jakarta, Oktober.

Online News Association [ONA], Digital Journalism Credibility Study, http://www.journalists.org/Programs/Study.htm, diakses 7 Pebruari 2002.

Pavlik, John V and Shawn McIntosh. (2004). Converging Media, An Introduction to Mass Communication. Boston : Pearson Education, Inc.

Pavlik, John V. (2001). Journalism and New Media: Columbia University Press

Pavlik, John V. (1998). "The Future of On-Line Journalism," chapter in Wickham, Kathleen, On-Line Journalism Perspective (CourseWise Publishing, Inc.).

Perebinossoff, Philippe. (2005). Programming for TV, Radio and The Internet, Strategi, Development and Evaluation. Second Edition : Focal Press. Elsevier Inc

Rahmat, Jalaludin. (2002). Metode Penelitian Komunikasi. Bandung : PT.Remaja Rosdakarya.

Salim, Peter dan Yenny Salim. (1991). Kamus Bahasa Indonesia Kontemporer. Jakarta: Modern English Press.

Scanlan, Christopher; The Web and The Future of Writing, Poynter Reporting and Writing Group Leader, http://www.poynter.org/centerpiece/062100.htm, diakses Juli 2002

Stovall, James Glen. (2004). Web Journalism of a New Medium. University of Alabama: Pearson Education Inc.

Straubhaar, Joseph dan Robert La Rose. (2002). Media Now: Communication Media in the Information Age: Australia: Wadsworth

Severin, Werner J and James W. Tankard. (2001). Communication Theories; Origin, Methods, and Uses in the Mass Media. Fifth Edition. University of Texas at Austin: Addison Wesley Longman Inc. 
84 Jurnal Ilmiah SCRIPTURA, Vol. 3, No. 1, Januari 2009: 69 - 84

Piliang, Yasraf Amir. (2004). Dunia yang Dilipat; Tamasya Melampaui Batas-Batas Kebudayaan. Yogyakarta : Jalasutra

Wallenius, Jaana. (2003). News Journalism on the Internet. University of Helsinki, Department of Communication. http:/www.imv.au/dkeng/academic/pdf_files/ Wallenius.pdf, diakses 7-08-2005. 